\title{
Climate Variability and Incidence Rate of Acute Respiratory Infections in Kendari City 2014-2018
}

\author{
Ramadhan Tosepu ${ }^{1}$, Yasnani Yasnani' ${ }^{2}$ Hariati Lestari ${ }^{3}$, La Ode Ahmah \\ Saktiansyah ${ }^{4}$, Rialdin Rialdin ${ }^{5}$ \\ \{ramadhan.tosepu@uho.ac.id ${ }^{1}$, yasnani_rahabuddin@yahoo.com ${ }^{2}$, lestarihariati@yahoo.co.id ${ }^{3}$, \\ saktiansyah89@gmail.com ${ }^{4}$, rialdin@ rocketmail.com $\left.{ }^{5}\right\}$ \\ ${ }^{1,2,3,4}$ Faculty of Public Health, Halu Oleo University, Indonesia \\ ${ }^{5}$ The graduate program, Faculty of Public Health Halu Oleo University, Indonesia
}

\begin{abstract}
Infection is the entry and proliferation of infectious agents in the tissues of the human body which results in cell damage or pathological tissue. The respiratory tract is an organ starting from the nose to the alveoli and its adnexal organs such as the sinuses, middle ear cavity, and pleura. The research used was descriptive observational research with an ecological time trend study. To the analysis, data was the Pearson correlation. This study aims to see the correlation between Climate Variability and the Incidence Rate of Acute Respiratory Infection in the Kendari City Region in 2014-2018. The data used are Climate Variability (Humidity, Minimum Temperature, Average Temperature, Maximum Temperature, and Rainfall), Population data, and ARI Case in Kendari City 2014-2018. The results of this study indicate that Humidity (\%) $\mathrm{r}=-0.306$ Medium correlation and negative pattern, Minimum Temperature (oC) $r=0.494$, Average Temperature (oC) $\mathrm{r}=0.232$ no correlation, Maximum Temperature (oC) $\mathrm{r}=0.700$ Correlation of strong and positive pattern correlation, and Rainfall (mm) r=-0.612 Relationship of strong correlation and negative pattern.
\end{abstract}

Keywords: Humidity, Temperature, Rainfall, Southeast Sulawesi, Indonesia.

\section{Introduction}

Acute Respiratory Infection (ARI) is a major cause of infectious morbidity and mortality in the world [1].Very high mortality rates in infants, children and the elderly, especially in countries with low and middle income every capita [2]. ARI is one of the leading causes of outpatient and hospitalization in health care facilities, especially in child care [3]. According to WHO the incidence of ARI in developing countries is $0.29 \%$ (151 million cases) and industrialized countries $0.05 \%$ or 5 million cases every year. Compared to 2015 the incidence of ARI increased by 18.8 billion instances and the number of deaths of 4 million cases each year [4].

In Indonesia cases of respiratory infections always rank first in the cause of infant mortality, and rank second in the cause of death in children and adolescents. A total of (36.4 $\%)$ infant mortality and $(25.7 \%)$ in children and adolescents were still growing in 2008, $(32.1$ $\%$ ) in $2009,(18.2 \%)$ in $2010,(38.8 \%)$, in $2013(25 \%)$, and $(4.4 \%)$ in 2018 due to ARI. Also, ARI is often on the list of the ten most common diseases in hospitals, and it is found that between 20-30\% of child deaths are caused by ARI [5].

According to the Health Profile of Southeast Sulawesi Province in 2017 as many as 28,720 cases of ARI, the trend of existing diseases is relatively not too different from year to 
year, where infectious diseases and infectious diseases still dominate. Infectious diseases listed in the ten highest diseases are diseases that routinely are on the list from year to year, which differ only from the position and sequence [6].

According to data from the Kendari City Health Office in 2017, the number of patients with acute respiratory infections was 38,813 patients, while in 2018 there were 38,979, this number indicates an increase in the incidence of severe respiratory infections from the previous year [7].

Climate change can affect health in humans by increasing the frequency of respiratory and cardiovascular diseases [8]. Climate and season factors are one of the main factors that influence the occurrence of infectious diseases [9]. Climate change can cause various phenomena such as air quality that gets worse [10]. Several studies have shown that air pollution is consistently associated with adverse health effects and has a measurable impact on respiratory diseases, cardiovascular disease and stroke [11].

Climate change will affect human health directly or indirectly, a direct effect on human health, namely the impact of temperature minimum and maximum temperature [12]. High temperatures with low humidity cause the body to dehydrate Cite easily. Extreme temperatures of extreme heat and cold cause high morbidity and mortality Cite. If high temperatures occur heat stroke while cold temperatures will occur frozen bite Cite, indirect effects are related to infectious diseases, one of which is acute respiratory infections caused by air pollution and erratic weather [11].

\section{Methods}

The research used was descriptive observational research with an ecological time trend study design with the Pearson correlation method. This study aims to look at the correlation between Climate Variability and Incidence Rate of Acute Respiratory Infection in Kendari City in 2014-2018. The data used are Climate Variability (Humidity, Minimum Temperature, Average Temperature, Maximum Temperature, and Rainfall), Population data, and ARI Case in Kendari City 2014-2018.

\section{Results}

Table 1. Climate variability and Incidence rate (IR) of Accurate Respiratory Infection

\begin{tabular}{|c|c|c|c|c|c|c|c|c|}
\hline Years & Population & $\begin{array}{c}\text { Case of } \\
\text { ARI }\end{array}$ & $\begin{array}{l}\text { I R } \\
(\%)\end{array}$ & Humidity & $\begin{array}{l}\text { Temperature } \\
\text { minimum }\end{array}$ & $\begin{array}{c}\text { A } \\
\text { Temperat } \\
\text { ure } \\
\text { average } \\
\end{array}$ & $\begin{array}{c}\text { Temperat } \\
\text { ure } \\
\text { maximu } \\
\mathrm{m}\end{array}$ & Rainfall \\
\hline 2014 & 325007 & 59978 & 18.45 & 82.67 & 23.35 & 27.00 & 31.82 & 188.64 \\
\hline 2015 & 341692 & 58146 & 17.02 & 83.00 & 23.55 & 26.99 & 31.40 & 132.78 \\
\hline 2016 & 353433 & 77096 & 21.81 & 83.67 & 24.71 & 27.76 & 31.82 & 179.05 \\
\hline 2017 & 365049 & 38813 & 10.63 & 84.75 & 24.34 & 27.39 & 31.36 & 252.43 \\
\hline 2018 & 376288 & 38979 & 10.36 & 82.92 & 22.25 & 27.23 & 28.97 & 202.78 \\
\hline
\end{tabular}


Table 2. Pearson correlation of Climate variability and Incidence rate of Accurate Respiratory Infection

\begin{tabular}{cccl}
\hline $\begin{array}{c}\text { Climate } \\
\text { Variable }\end{array}$ & $\begin{array}{c}\text { Pearson } \\
\text { correlation }\end{array}$ & $\begin{array}{c}\text { Significant } \\
\text { (two-tailed) }\end{array}$ & \multicolumn{1}{c}{ Note } \\
\hline $\begin{array}{c}\text { Humidity }(\%) \\
\begin{array}{c}\text { Temperature } \\
\text { Minimum } \\
\left({ }^{\circ} \mathrm{C}\right)\end{array}\end{array}$ & -0.306 & 0.616 & $\begin{array}{l}\text { Medium correlation and } \\
\text { negative direction }\end{array}$ \\
$\begin{array}{c}\text { Temperature } \\
\text { Average }(\mathrm{C})\end{array}$ & 0.494 & 0.397 & $\begin{array}{l}\text { The correlation relationship is } \\
\text { in the positive direction }\end{array}$ \\
$\begin{array}{c}\text { Temperature } \\
\text { Maximum } \\
\left({ }^{\circ} \mathrm{C}\right)\end{array}$ & 0.700 & 0.707 & $\begin{array}{l}\text { Weak correlation and positive } \\
\text { direction }\end{array}$ \\
$\begin{array}{c}\text { Rainfall } \\
(\mathrm{mm})\end{array}$ & -0.612 & 0.188 & $\begin{array}{l}\text { Strong correlation and positive } \\
\text { direction relationship }\end{array}$ \\
\hline
\end{tabular}

Air Humidity based on the results of the study shows that the annual air humidity during the 2014-2018 period in Kendari City is at $82.67 \%, 83 \%, 83.67 \%, 84.75 \%$, and $82.92 \%$. From the results of the data analysis between air humidity and the case rate of Incidence of ARI in 2014-2018, the power gained was a moderate correlation relationship and a negative direction

Minimum temperature based on the results of the study can be seen that the annual minimum temperature during the period 2014-2018 in Kendari City is 23.35 0C, 23.55 0C, $27.410 \mathrm{C}, 24.34$ 0C, and 22.25 0C. From the results of data analysis between the minimum temperature and the number of cases of the Incidence Rate of ARI in 2014-2018, obtained the minimum strength of temperature $r=0.494$. The correlation relationship is in a positive direction.

Average temperature based on the results of the study can be seen that the average annual temperature during the period 2014-2018 in Kendari City is 27 0C, 26.99 0C, 27.76 0C, 27.39 0C, and 27.23 0C From the results of the analysis Data between Average Temperature and Incidence Rate of ARI cases in 2014-2018, obtained by Average Temperature strength $\mathrm{r}=$ 0.232 Relationship between weak correlation and positive direction.

Maximum temperature based on the results of the study can be seen that the maximum annual temperature for the period 2014-2018 in Kendari City is 31.82 0C, 31.40 0C, 31.82 0C, $41.360 \mathrm{C}$ and $28.920 \mathrm{C}$ From the results of data analysis between maximum temperatures with the case rate of Incidence of ARI in 2014-2018, the maximum temperature strength was $\mathrm{r}=$ 0.700 The relationship was a strong correlation and a decisive direction

Rainfall-based on the results of the study can be seen that annual rainfall during the period 2014-2018 in Kendari City is $188.64 \mathrm{~mm}, 132.78 \mathrm{~mm}, 179.05 \mathrm{~mm}, 252.43 \mathrm{~mm}$ and $202.78 \mathrm{~mm}$. From the results of data analysis between rainfall and the number of cases of Incidence Rate of ARI in 2014-2018, rainfall was obtained $r=-0.612$ Relationship between strong correlation and negative direction.

\section{Discussion}

Humidity is a common term that sometimes includes water in the liquid phase in the soil or atmosphere. In writing the time will be used to indicate water vapor in the atmosphere. In atmospheric science, the word dry air means that the mixture is evenly distributed between permanent gases, and the term wet air is used to indicate a mix of dry air and water vapour [13]. 
The high incidence of ARI in an area illustrates the air humidity in the area both for the growth and development of microorganisms that cause disease. According to the Ministry of Health Republic of Indonesia Number 829/Menkes/SK/VII/1999 concerning housing health requirements humidity is considered good if it meets $40 \%-70 \%$, and is terrible if it is less than $40 \%$ or more than $70 \%$ while the air humidity in the city of Kendari reaches $84.75 \%$, moisture is very height is right for fungal growth and causes bacteria to last longer [14]. The researchers stated that statistically there was no significant relationship between air humidity and the incidence of non-pneumonia ARI [15].

Temperature is the degree of heat or cold measured by an absolute scale using a thermometer [16]. The unit of temperature commonly used is degrees Celsius $\left({ }^{\circ} \mathrm{C}\right)$, while in England and some other countries expressed in degrees Fahrenheit $\left({ }^{0} \mathrm{C}\right)$ [17]. High temperatures or heat can cause fatigue in humans because the heat causes a lot of sweat to be released, so it becomes dehydrated. Likewise with children and toddlers can be affected by flu, cough, runny nose, fever, respiratory tract disorders, colds, digestive disorders, allergies, and the most dangerous is Upper Respiratory Tract Infection [18]. Also, the increase in environmental temperature will also affect the impact of air pollution, especially in urban areas and affect individuals with chronic diseases such as heart disease, asthma and other respiratory diseases [19].

Rain intensity is the amount of rainfall every unit of time. The nature of clouds that can cause rain by humans is used to make artificial rain. In accelerating rain, people give hygroscopic substances as condensation nuclei (silver iodide, ice crystals, dry ice or solid $\mathrm{CO}_{2}$ ). These substances are sprinkled into the air using airplanes [20].

Increasing rainfall will affect the effect of changes in temperature and humidity. Winter in tropical countries is followed by an increase in cases of respiratory infections.From the results of the bivariate analysis of the Pearson Correlation $(r)$, it was found that the correlation between Rainfall and the Incidence Rate of the ISPA was -0,612. This shows that there is a strong relationship between rainfall and the Incidence Rate of ISPA. While the direction of the link is negative because the $r$ value is negative, meaning that the higher the rainfall, the lower the ISPA Incidence Rate.

The test uses a two-sided test with a significance level of $\alpha=5 \%$ where the significance value $(0.272>0.05)$ means that there is no significant relationship between rainfall and the incidence rate. Increased cases of respiratory infections are affected by extreme rainfall which causes an area to cool [21].

\section{Conclusion}

Our finding that Humidity (\%) $r=-0.306$ Medium correlation and negative pattern, Minimum Temperature $\left({ }^{\circ} \mathrm{C}\right) \quad r=0.494$, Average Temperature $\left({ }^{\circ} \mathrm{C}\right) \quad r=0.232$ no correlation, Maximum Temperature $\left({ }^{\circ} \mathrm{C}\right) r=0.700$ Correlation of strong and positive pattern correlation, and Rainfall $(\mathrm{mm}) r=-0.612$ Relationship of strong correlation and negative pattern.

\section{Reference}

[1] C. A. Camargo, "Chapter 112 - Vitamin D, Acute Respiratory Infection, and Asthma/Chronic Obstructive Pulmonary Disease," in Vitamin D (Fourth Edition), D. Feldman, Ed., ed: Academic Press, pp. 1095-1120, 2018.

[2] A. D. Lopez, C. D. Mathers, M. Ezzati, D. T. Jamison, and C. J. Murray, "Global and regional burden of disease and risk factors, 2001: systematic analysis of population health data," The lancet, vol. 367, pp. 1747-1757, 2006. 
[3] W. H. Organization, "The Bolivian health system and its impact on health care use and financial risk protection," World Health Organization, 2006.

[4] M. Whaley, "Role of Influenza among Adult Respiratory Hospitalizations: a Systemic Review," , 2015.

[5] K. K. R. Indonesia, "Basic health research 2018,", 2019.

[6] D. K. P. S. Tenggara, "Profile of Health Southeast Sulawesi Province,", 2017.

[7] D. K. K. Kendari, "Profile of Health Kendari,", 2018.

[8] D. R. Silva, V. P. Viana, A. M. Müller, F. P. Livi, and P. d. T. R. Dalcin, "Respiratory viral infections and effects of meteorological parameters and air pollution in adults with respiratory symptoms admitted to the emergency room," Influenza and other respiratory viruses, vol. 8, pp. 42-52, 2014.

[9] B. Cui, D. Zhang, H. Pan, F. Zhang, J. Farrar, F. Law, et al., "Viral aetiology of acute respiratory infections among children and associated meteorological factors in southern China," BMC Infectious Diseases, vol. 15, p. 124, 2015/03/13, 2015.

[10] G. Chakhunashvili, A. L. Wagner, A. Machablishvili, I. Karseladze, O. TarkhanMouravi, K. Zakhashvili, et al., "Implementation of a sentinel surveillance system for influenza-like illness (ILI) and severe acute respiratory infection (SARI) in the country of Georgia, 2015-2016," International Journal of Infectious Diseases, vol. 65, pp. 98-100, 2017/12/01/, 2017.

[11] S. D. Passos, R. E. Gazeta, A. P. Felgueiras, P. C. Beneli, and M. d. S. Coelho, "Do pollution and climate influence respiratory tract infections in children?," Revista da Associação Médica Brasileira, vol. 60, pp. 276-282, 2014.

[12] Z. Chen, W. Ji, Y. Wang, Y. Yan, H. Zhu, X. Shao, et al., "Epidemiology and associations with climatic conditions of Mycoplasma pneumoniae and Chlamydophila pneumoniae infections among Chinese children hospitalized with acute respiratory infections," Italian journal of pediatrics, vol. 39, p. 34, 2013.

[13] R. B. Keey, Drying: principles and practice vol. 13: Elsevier, 2013.

[14] K. K. R. Indonesia, "Regulation of Health ", 1999.

[15] J.-B. du Prel, W. Puppe, B. Gröndahl, M. Knuf, F. Weigl, F. Schaaff, et al., "Are meteorological parameters associated with acute respiratory tract infections?," Clinical infectious diseases, vol. 49, pp. 861-868, 2009.

[16] R. P. Benedict and B. Xvi, Fundamentals of temperature, pressure, and flow measurements: John Wiley \& Sons, 1984.

[17] H. Stimson, "Heat units and temperature scales for calorimetry," American Journal of Physics, vol. 23, pp. 614-622, 1955.

[18] Y.-K. Lin, C.-K. Chang, S.-C. Chang, P.-S. Chen, C. Lin, and Y.-C. Wang, "Temperature, nitrogen dioxide, circulating respiratory viruses and acute upper respiratory infections among children in Taipei, Taiwan: A population-based study," Environmental Research, vol. 120, pp. 109-118, 2013/01/01/, 2013.

[19] D. W. Dockery and C. A. Pope, "Acute respiratory effects of particulate air pollution," Annual review of public health, vol. 15, pp. 107-132, 1994.

[20] A. Akalily and D. Harisuseno, "Artificial Rain Technology As An Alternative Increasing Sutami Reservoir Volume In Effort Tackling Drought Due To Global Climate Change."

[21] A. Annan, F. Ebach, V. M. Corman, R. Krumkamp, Y. Adu-Sarkodie, A. M. EisHübinger, et al., "Similar virus spectra and seasonality in paediatric patients with acute respiratory disease, Ghana and Germany," Clinical Microbiology and Infection, vol. 22, pp. 340-346, 2016/04/01/, 2016. 